\title{
Article \\ Utilizing Red Spotted Apollo Butterfly Transcriptome to Identify Antimicrobial Peptide Candidates against Porphyromonas gingivalis
}

\author{
Kang-Woon Lee ${ }^{1,+}{ }^{\dagger}$ Jae-Goo Kim ${ }^{2,+}$, Karpagam Veerappan ${ }^{3}$, Hoyong Chung ${ }^{3}{ }^{\circledR}$, Sathishkumar Natarajan ${ }^{3}(\mathbb{D}$, \\ Ki-Young Kim ${ }^{2,4, *}$ and Junhyung Park ${ }^{3, *}$ \\ 1 Holoce Ecosystem Conservation Research Institute (HECRI), Hweongsung 25257, Gangwon-do, Korea; \\ holoce@hecri.re.kr \\ 2 Graduate School of Biotechnology, Kyung Hee University, Yongin-si 17104, Gyeonggi-do, Korea; \\ zxcv913@naver.com \\ 3 3BIGS Co. Ltd., 156, Gwanggyo-ro, Yeongtong-gu, Suwon-si 16506, Gyeonggi-do, Korea; \\ karpagam@3bigs.com (K.V.); hychung@3bigs.com (H.C.); sathish@3bigs.com (S.N.) \\ 4 Department of Genetics and Biotechnology, College of Life Science, Kyung Hee University, \\ Yongin-si 17104, Gyeonggi-do, Korea \\ check for \\ updates \\ * Correspondence: kiyoung@khu.ac.kr (K.-Y.K.); jhpark@3bigs.com (J.P.) \\ $\dagger$ These authors contributed equally to this work.
}

Citation: Lee, K.-W.; Kim, J.-G.; Veerappan, K.; Chung, H.; Natarajan, S.; Kim, K.-Y.; Park, J. Utilizing Red Spotted Apollo Butterfly Transcriptome to Identify Antimicrobial Peptide Candidates against Porphyromonas gingivalis. Insects 2021, 12, 466. https://doi.org/ $10.3390 /$ insects 12050466

Academic Editors: Maria José Sánchez-Muros, Cristina Elena

Trenzado Romero, Amalia Pérez-Jiménez and Eva E. Rufino-Palomares

Received: 21 April 2021

Accepted: 17 May 2021

Published: 18 May 2021

Publisher's Note: MDPI stays neutral with regard to jurisdictional claims in published maps and institutional affiliations.

Copyright: (c) 2021 by the authors. Licensee MDPI, Basel, Switzerland. This article is an open access article distributed under the terms and conditions of the Creative Commons Attribution (CC BY) license (https:// creativecommons.org/licenses/by/ $4.0 /)$.
Simple Summary: Infections caused by bacteria, fungi, or viruses possess serious threat to human health and life. This is well realized in the current COVID-19 pandemic scenario. Antimicrobial peptides (AMPs) are a natural line of defense in many organisms, especially insects which survive in extreme niches. Here we identified AMPs from red spotted apollo butterflies found at high altitudes in Russia, China, and Korea. The larval development stage occurs on the months of December to April, when there are very low temperatures. The insects natural defense mechanism might contribute to withstand this condition, which is our point of interest, and we utilized the genomic information to identify AMPs from red spotted butterflies. The obtained AMPs were tested against a list of pathogenic bacteria and fungi. Finally, we obtained one promising candidate active against Porphyromonas gingivalis, a causative organism for periodontitis. With further validations, this could be a lead antimicrobial agent in future.

Abstract: Classical antibiotics are the foremost treatment strategy against microbial infections. Overuse of this has led to the evolution of antimicrobial resistance. Antimicrobial peptides (AMPs) are natural defense elements present across many species including humans, insects, bacteria, and plants. Insect AMPs are our area of interest, because of their stronger abilities in host defense. We have deciphered AMPs from an endangered species Parnassius bremeri, commonly known as the red spotted apollo butterfly. It belongs to the second largest insect order Lepidoptera, comprised of butterflies and moths, and lives in the high altitudes of Russia, China, and Korea. We aimed at identifying the AMPs from the larvae stages. The rationale of choosing this stage is that the P. bremeri larvae development occurs at extremely low temperature conditions, which might serve as external stimuli for AMP production. RNA was isolated from larvae (L1 to L5) instar stages and subjected to next generation sequencing. The transcriptomes obtained were curated in in-silico pipelines. The peptides obtained were screened for requisite AMP physicochemical properties and in vitro antimicrobial activity. With the sequential screening and validation, we obtained fifteen candidate AMPs. One peptide TPS-032 showed promising antimicrobial activity against Porphyromonas gingivalis, a primary causative organism of periodontitis.

Keywords: Parnassius bremeri; transcriptome; antimicrobial peptide; Porphyromonas gingivalis; endangered species 


\section{Introduction}

Humans are privileged by having a strong innate and adaptive immune architecture, while smaller organisms like insects are solely dependent on innate immune systems. Defensive antimicrobial peptides (AMPs) are one of the key components of innate immune systems observed in different organisms. AMPs were proven effective against a broad range of pathogenic bacteria, fungi, parasites, and viruses [1]. Albeit their exceptional potency against pathogens, these have been little utilized until recently. The overuse or inappropriate dosage of classical antibiotics has developed a serious problem of antimicrobial resistance [2,3]. Thus, AMPs can be considered as an alternative pharmacological resource from nature confronting antibiotic resistant microorganisms.

Although AMPs are widely observed in both invertebrates and vertebrates, we are interested in studying insect AMPs as they are crucial for their survival in pathogen rich habitats $[4,5]$. Parnassius bremeri (P. bremeri), commonly referred as the red spotted apollo butterfly, has been chosen for this study. P. bremeri is listed as an endangered species, as their existence around the world has been significantly reducing because of global warming and shrinking of its habitat [6]. It belongs to the second largest insect order, Lepidoptera, which includes butterfly and moth species. Different families of AMPs (like cecropins, attacins, moricins, lebocins, gloverins) which are documented from this order, have been well summarized and discussed elsewhere [7-9]. Knowing the divergence and efficacy of Lepidopteran derived AMPs, we utilized the transcriptome of $P$. bremeri to identify novel AMPs. The identified peptides were then tested against diverse pathogenic bacterial and fungal species.

Oral mucosa is a niche to diverse microorganism, and any alteration in the microbiome leads to diseases like dental caries, periodontitis, and gingivitis [10]. Periodontitis is an oral inflammatory disease caused by gram-negative bacteria, especially Porphyromonas gingivalis. The treatment for periodontitis involves mechanical therapy such as scaling and then antibiotics. However, improper use of antibiotics has caused the emergence of antimicrobial resistant strains. Thus, AMP can serve as an alternative form of treatment [11-13]. In this study we found that Peptide TPS- 032 showed antimicrobial activity against $P$. gingivalis. Also, the peptides were tested for cytotoxicity using human keratinocyte (HaCaT) cells. HaCaT cell lines are highly proliferating epidermal cells with an almost normal phenotype. This cell line provides a virtually infinite supply of resembling cells, guaranteeing tremendous reproducibility, and is of great relevance to human epidermal-induced irritation.

\section{Materials and Methods}

\subsection{Strains Preparation}

The bacterial and fungal strains used in this study were obtained from the KTCC (Korean Collection for Type Cultures), KACC (Korean Agricultural Culture Collection) or CCARM (Canadian Centre for Agri-Food Research in Health and Medicine). The bacterial or fungal strains were inoculated into the appropriate medium and grown at the temperatures shown in Table 1 . All strains were stored in $20 \%$ glycerol at $-70{ }^{\circ} \mathrm{C}$.

\subsection{P. bremeri Rearing and RNA Isolation}

The P. bremeri rearing was followed, as reported earlier [6], in field conditions (Hweongsung, Korea). Briefly, eggs were manually attached to the fallen oak tree leaves in double net cages $(0.1 \times 0.3 \mathrm{~mm}$ mesh) for 180 days. The eggs were then transferred to young larval cage $(40 \times 50 \times 70 \mathrm{~cm})$, and the resulting newly hatching larvae were collected into a plastic petri dish $(10 \mathrm{~cm}$ diameter $\times 4 \mathrm{~cm}$ height $)$ with a supplement of the host plant, Sedum kamtschaticum. At the 4th instar (L4), the larvae were separated into 30 individuals and kept in a metal cage $(71 \times 51 \times 88 \mathrm{~cm}$ covered with $1 \times 1 \mathrm{~mm}$ metal mesh) with host plants. Total RNA was isolated from 1st instar to L1 to 5th instar to L5 stages using Trizol reagent (Invitrogen, Carlsbad, CA, USA), according to the manufacturer's instruction. 
Table 1. Strains used in this study and culture conditions.

\begin{tabular}{|c|c|c|c|c|}
\hline Stains & Description & Medium & Temperature $\left({ }^{\circ} \mathrm{C}\right)$ & Atmosphere \\
\hline Staphylococcus epidermidis & KACC 12454 & NB & 30 & Aerobic \\
\hline Klebsiella oxytoca & КСТC 1686 & NB & 37 & Aerobic \\
\hline Salmonella typhimurium & CCARM 0240 & NB & 37 & Aerobic \\
\hline Escherichia coli & KACC 11598 & TSB & 37 & Aerobic \\
\hline Enterococcus faecalis & CCARM 5511 & TSB & 37 & Aerobic \\
\hline Enterococcus faecium & KACC 11954 & TSB & 37 & Aerobic \\
\hline Pseudomonas aeruginosa & KACC 14021 & TSB & 37 & Aerobic \\
\hline Staphylococcus aureus & CCARM 3505 & TSB & 37 & Aerobic \\
\hline Streptococcus mutans & KACC 16833 & TSB & 37 & Aerobic \\
\hline Staphylococcus epidermidis & KACC 13234 & TSB & 37 & Aerobic \\
\hline $\begin{array}{l}\text { Fusobacterium nucleatum } \\
\text { subsp. Nucleatum }\end{array}$ & КСТС 2640 & $\mathrm{BHI}$ & 37 & Aerobic \\
\hline Actinomyces viscosus & КСТС 9146 & $\mathrm{BHI}$ & 37 & Anaerobic \\
\hline Propionibacterium acnes & CCARM 9009 & BHI & 37 & Anaerobic \\
\hline Porphyromonas gingivalis & КСТС 5352 & Modified TSB & 37 & Anaerobic \\
\hline Streptococcus sobrinus & КСТС 5809 & Modified TSB & 37 & Anaerobic \\
\hline Candida albicans & КСТС 7965 & YPD & 30 & Aerobic \\
\hline Candida tropicalis & КСТС 7212 & YPD & 30 & Aerobic \\
\hline Candida parapsilosis & KACC 49573 & YPD & 30 & Aerobic \\
\hline $\begin{array}{l}\text { Candida tropicalis } \\
\text { var. tropicalis }\end{array}$ & KCTC 17762 & YPD & 30 & Aerobic \\
\hline $\begin{array}{l}\text { Candida parapsilosis } \\
\text { var. parapsilosis }\end{array}$ & KACC 45480 & YPD & 30 & Aerobic \\
\hline Candida glabrata & КСТС 7219 & YPD & 30 & Aerobic \\
\hline Pichia guilliermondii & КСТС 7211 & YPD & 30 & Aerobic \\
\hline $\begin{array}{c}\text { Filobasidiella neoformans } \\
\text { var. bacillispora }\end{array}$ & КСТC 17528 & YPD & 30 & Aerobic \\
\hline
\end{tabular}

NB (Nutrient broth), TSB (Tryptic Soy Broth), BHI (Brain-Heart Infusion), Modified TSB (TSB supplemented with 2\% sheep blood) and YPD (Yeast Peptone Dextrose).

\subsection{Next Generation Sequencing and Assembly}

The integrity of isolated RNAs were analyzed using the Bioanalyzer 2100s system (Agilent technologies, Inc., Santa Clara, CA, USA). The RNA integrity Number (RIN) $>7$ was set as RNA QC to proceed to the next step of cDNA library construction (Truseq Stranded mRNA Prep Kit (Illumina Technologies, San Diego, CA, USA)). Further, constructed cDNA libraries were sequenced using an Illumina NovaSeq 6000 platform to generate $100 \mathrm{bp}$ paired end reads. This was followed by quality checking by FASTQC [14], adaptor trimming using Trimmomatic [15] and de novo assembly in the Trinity program [16] with default parameters. A Cluster Database at High Identity with Tolerance (CD-HIT-EST) tool [17] was used to remove the redundancy transcripts with an identify threshold of $95 \%$ sequence similarity. The completeness of the assembled transcriptome was analyzed with gVolante against Arthropoda [18].

\subsection{AMP Screening}

The longest ORF per transcript was identified by the TransDecoder [16] to predict peptide and protein fragment. The AMP prediction was carried out as established previously. Briefly, the physiochemical properties (length, pI, charge), aggregation propensity (in vivo), aggregation propensity (in vitro), and antimicrobial region were determined by Pepstats [19], Tango [20], Aggrescan [21] and AMPA tools [22] respectively, with given cutoffs detailed in Table 2. The peptides which satisfied all of these conditions were considered for successive filtration. To find the novelty of the obtained peptides, the amino acid sequences were BLAST against CAMP (Collection of Anti-Microbial Peptides) [23], ADAM (A Database of Anti-Microbial Peptides) [24], and APD (The Antimicrobial Peptide Database) [25] databases. Peptides with a similarity score $<80$ were considered novel. Finally, we used several classifiers from CAMP and ADAM databases, as mentioned in 
Table 2, to predict the given input peptide as AMP or non-AMP. The peptides which passed through all of these filters were then subjected to in house in-silico prediction strategies.

Table 2. Antimicrobial peptide properties prediction and filtration.

\begin{tabular}{|c|c|c|c|c|}
\hline Propensity & Tools & Descriptions/Parameters & Cutoff & No. of Sequences \\
\hline & & Total Protein fragments & & 266,300 \\
\hline \multirow{4}{*}{ Physicochemical } & Pepstats & Peptide Length & $\geq 2$ to 50 & 189,818 \\
\hline & Pepstats & Charge & $>0(+)$ & 128,625 \\
\hline & Pepstats & Isoelectric Point(pI) & $\geq 8$ to $\leq 12$ & 88,951 \\
\hline & AMPA & Stretch & $\geq 1$ & 152,758 \\
\hline \multirow{3}{*}{$\begin{array}{l}\text { Aggregation } \\
\text { (Invivo) }\end{array}$} & Tango & AGG & $\leq 500$ & 157,940 \\
\hline & Tango & Helix & $\geq 0$ Helix $\leq 25$ & 179,511 \\
\hline & Tango & Beta & $\geq 25$ Beta $\leq 100$ & 88,470 \\
\hline $\begin{array}{l}\text { Aggregation } \\
\text { (Invitro) }\end{array}$ & Aggrescan & $\mathrm{Na} 4 v S S$ & $\geq-40 \mathrm{Na} 4 \mathrm{vSS} \leq 60$ & 149,072 \\
\hline Similarity & BlastP & Similarity & $<80$ & 25,246 \\
\hline \multirow{5}{*}{ AMP } & & $\begin{array}{l}\text { Support Vector Machine (SVM) } \\
\text { classifier }\end{array}$ & $>0.5, \mathrm{AMP}$ & 7574 \\
\hline & CAMP & Random Forest Classifier & $>0.5, \mathrm{AMP}$ & 8571 \\
\hline & ADAM & $\begin{array}{c}\text { Artificial Neural Network (ANN) } \\
\text { classifier }\end{array}$ & AMP & 12,051 \\
\hline & & Discriminant Analysis classifier & $>0.5, \mathrm{AMP}$ & 9127 \\
\hline & & $\begin{array}{l}\text { Support Vector Machine (SVM) } \\
\text { classifier }\end{array}$ & $>0.5, \mathrm{AMP}$ & 17,976 \\
\hline Final & & & & 3570 \\
\hline
\end{tabular}

CAMP—Collection of Anti-Microbial Peptides, ADAM—A Database of Anti-Microbial peptides.

\subsection{Peptide Synthesis and Antimicrobial Activity}

Fifteen putative novel peptides were synthesized using solid-phase peptide synthesis methods at Lugen Sci Co. Ltd. (Bucheon, Korea). Then, each peptide was purified to $>95 \%$ by high-performance liquid chromatography, and the purity was confirmed by mass spectrometry analysis. The peptides were dissolved in distilled water at a concentration of $1 \mathrm{mg} / \mathrm{mL}$. To assess the anti-microbial activity, a broth microdilution method assay was used [26]. The bacterial or fungal strains were inoculated into the appropriate medium overnight at the proper culture temperature as shown in Table 1 . The bacterial or fungal strains were adjusted at OD600 to 0.1 or 0.01 , with the final compound concentrations ranging from 3.125 to $100 \mu \mathrm{g} / \mathrm{mL}$. The growth control without treatment and the sterilized medium control were included in each experiment, and oxytetracycline or miconazole was used as the positive control. The growth rate was measured at OD600 using a microplate reader (BioTek Instruments, Seoul, Korea) at $24 \mathrm{~h}$.

\subsection{Cell Viability Assays}

The cytotoxicity of the three peptides against HaCaT cells was tested using an MTT assay [27]. Briefly, HaCaT cells in Dulbecco's Modified Eagle's Medium (DMEM), at a density of $10^{4}$ cells per well of a 96-well plate, are cultured for $24 \mathrm{~h}$. A serum-free medium containing various concentrations of peptides were added to the wells. After additional incubation for 24 h, MTT (3-(4,5-dimethyl-thiazol-2-yl)-2,5-diphenyltetrazolium bromide, Sigma) in PBS was added to a final concentration of $0.5 \mathrm{mg} / \mathrm{mL}$, followed by incubation for $3 \mathrm{~h}$ at $37^{\circ} \mathrm{C}$. This solution was then removed, and cells were suspended in $100 \mathrm{~mL}$ of DMSO (Dimethyl Sulfoxide, Junsei) for $10 \mathrm{~min}$. Absorbance was calculated from optical density (OD540) values measured using a microplate reader (BioTek Instruments, Seoul, Korea). Three independent experiments were carried out in triplicate. 


\section{Results}

Three biological replicates for each larva (L1-L5) instar stage were sequenced. Due to lack of a reference genome, we tried de novo assembly of the P. bremeri transcriptome using a Trinity assembler. The assembly resulted in 48,672 unigenes with the average length of 1,710 base pairs. Unigenes with the length $>300$ base pairs were considered for further processing. The completeness assessment score, or the BUSCO validation, was about $98.50 \%$.

\subsection{In Silico AMP Prediction}

We have used next generation sequencing technology as a tool to decipher potent AMPs from red spotted apollo butterflies. The application of our in-silico AMP screening platform in insects has been successfully employed in our previous studies. Although AMPs are prevalently produced across species, certain structural features are important for their effective antimicrobial activity. Essentially the cationic and amphipathic structure is crucial for the bactericidal or fungicidal functions. These crucial physiological characteristics has been included in our screening schema that includes charge, isoelectric point, and antimicrobial spots (Table 1). Further, the naturally occurring AMPs mostly consist of 10 to 100 amino acid lengths [28]; we here considered the range of $\geq 2$ to 50 amino acids to elude the high peptide manufacturing cost. We also measured the aggregation propensity in two different tools: Tango, which measures the aggregation in solution, and AGGRESCAN, to predict in vivo aggregation (bacterial cell membrane). Peptides which satisfy the given physicochemical propensity were then blasted against three antimicrobial databases to identify the novel peptide. Then, peptides were again run against supervised machine learning classifiers in CAMP and ADAM, such as Support Vector Machine (SVM), Random Forests (RF) and Artificial Neural Network (ANN) for AMP and non-AMP prediction. Peptides which satisfy all of the parameters were chosen for further downstream processing.

\subsection{Antimicrobial Activity}

The final peptides (Table 2) were again filtered with our in-house AMP prediction system (Korea patent application number: 10-2019-0019906). Fifteen peptides were finally selected and tested for anti-microbial activity against sixteen bacterial and eight fungal species. Out of the fifteen peptides, only three showed (TPS-029, TPS-032, TPS-035) positive antibacterial or antifungal effects (Table S1) in the screening test. Distinctively, the antimicrobial activity against $P$. gingivalis or F. neoformans var. bacillispora, or P. guilliermondii were noted. The broth microdilution method was used to identify the minimum inhibitory concentration of each peptide, presented here in Table 3. Oxytetracycline and miconazole were used as positive controls. Among the three peptides, TPS-032 were more effective against $P$. gingivalis. TPS-029 showed antifungal activity against $F$. neoformans var. bacillispora. The antifungal activities of TPS-032 and TPS-035 are displayed against $P$. guilliermondii (Table 3).

Table 3. Minimum inhibitory concentrations. [ $\mu \mathrm{M}(\mu \mathrm{g} / \mathrm{mL})]$.

\begin{tabular}{cccccc}
\hline & Sequence & Mw (Da) & $\begin{array}{c}\text { Porphyromonas } \\
\text { gingivalis } \\
\text { (KCTC5352) }\end{array}$ & $\begin{array}{c}\text { Filobasidiella } \\
\text { neoformans var. } \\
\text { Bacillispora } \\
\text { (KCTC17528) }\end{array}$ & $\begin{array}{c}\text { Pichia } \\
\text { guilliemondii } \\
\text { (KCTC7211) }\end{array}$ \\
\hline $\begin{array}{c}\text { Oxytetracycline } \\
\text { Miconazole }\end{array}$ & & 460.4 & $108.6(50)$ & ND & ND \\
TPS-029 & RLFNYGLFSSKIIKHTIK & 2165.1 & ND & $7.5(3.125)$ & $7.5(3.125)$ \\
TPS-032 & RVLTHVFKCKLKLR & 1741.41 & $>46.2(>100)$ & $23.1(50)$ & $>46.2(>100)$ \\
TPS-035 & RCCKLVFR & 1024.42 & $14.4(25)$ & $>57.4(>100)$ & $28.7(50)$ \\
\hline
\end{tabular}

$\mathrm{ND}$-not detected, $\mathrm{Mw}$ - molecular weight. 


\subsection{Cell Viability}

Although AMPs exhibit antibacterial or antifungal effects, cytotoxicity towards normal mammalian cells prevents its use as a pharmacological agent. Here, a human keratinocyte cell line (HaCaT) was used to test the cytotoxicity of the three peptides. TPS-035 showed cell viability above $80 \%$ at $14.4 \mu \mathrm{M}$, at which MIC against $P$. gingivalis was observed (Figure 1a). However, TPS-029 and TPS-032 at increased concentrations displayed reduced viable cells (Figure $1 b, c)$.

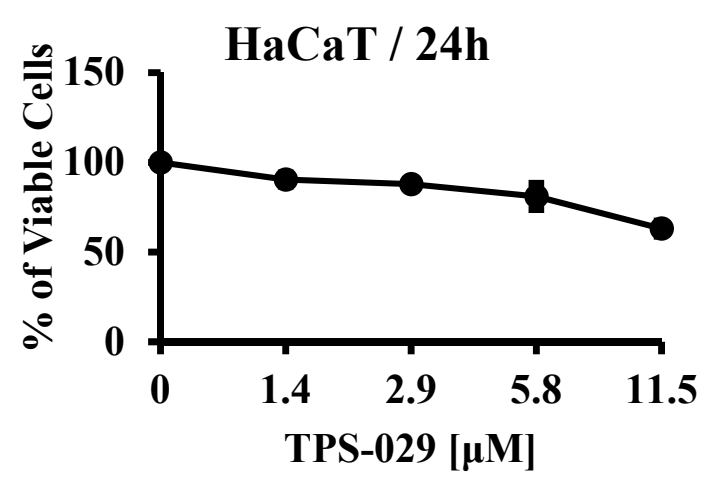

(a)

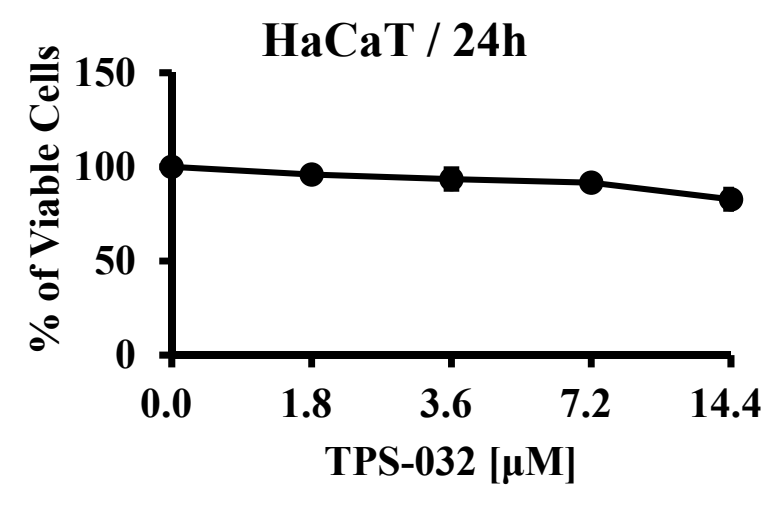

(b)

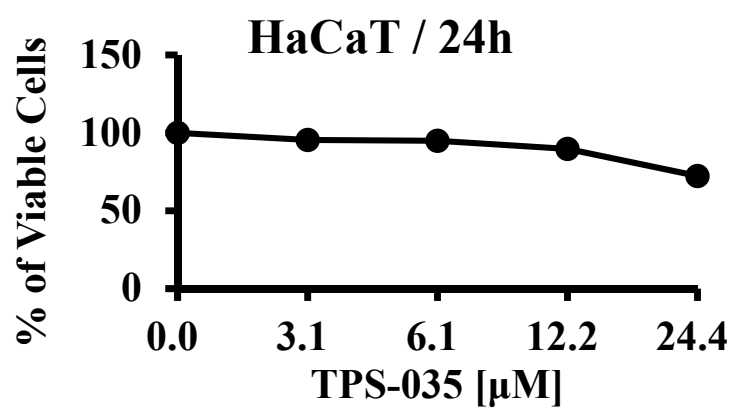

(c)

Figure 1. Cell viability assay. Effect of peptides (a) TPS-029 (b) TPS-032 and (c) TPS-035 on the growth of HaCaT cells at 24 h.

\section{Discussion}

The quest for new AMP candidates is necessary to prevent or treat the evolving antimicrobial resistance. Pertaining to this, we have developed an in-silico AMP identification system harnessing genomic source, using previously identified potential AMP candidates from insects [4,5]. Insect AMPs are diversified in their structure, and show a broad range of activities such as being antibacterial, antifungal, antiviral, anticancer, and anti-parasitic. We report for the first time AMPs from red spotted apollo butterflies, an endangered species as listed in the International Union for Conservation of Nature and Natural Resource (IUCN) red list [6]. We have documented and deciphered their transcriptome in the process of identifying AMPs which might serve as a resource for future exploration. P. bremeri larva developmental stages occur during December to May in high altitudes, wherein extreme cold conditions prevail [6]. Thus, we are curious to identify the AMPs possibly involved in protecting the larvae.

The in-silico AMP identification schema includes the physicochemical propensity necessary for the AMP activity. Predominant characteristics of AMPs include cationicity, low aggregation in solution, higher aggregation in vivo, hydrophobicity, and amphipathicity [29-31]; all of these were considered in our screening platform. Although we attained relatively more candidates in the initial steps involving length, pI, charge, AMP spots, aggregation properties and trained classifiers from prominent AMP databases, the consecu- 
tive screening (Korea patent number: 10-2019-0019906) reduced the numbers considerably. Thus, stringent screening resulted in a few candidates to be tested in vitro. Fifteen peptides were tested against several bacterial and fungal strains, but only three peptides showed antibacterial and antifungal activity. P. gingivalis is a human pathogenic bacteria causing periodontitis [32,33], and its noted association with other disease like Alzheimer's disease $[34,35]$ is a serious threat to human health. Identifying novel drug candidates against $P$. gingivalis will add value to a treatment regimen. TPS-032 exhibited strong anti P. gingivalis activity. While all three peptides showed antifungal activity, they are less effective than the positive control. HaCaT cells exert normal epidermal phenotypes, and have a greater human relevance than animal derived cells. Hence, cytotoxicity towards $\mathrm{HaCaT}$ cells was measured for three peptide candidates. Little or no cytotoxicity was observed when treated with TPS-032, which shows its specificity towards P. gingivalis. In total, TPS-032 showed antibacterial and antifungal activity with less cytotoxicity. With further experimental validations, TPS-032 could serve as a potential lead candidate alone or in combination to treat $P$. gingivalis infections.

Supplementary Materials: The following are available online at https:/ /www.mdpi.com/article/10 .3390/insects12050466/s1, Table S1: peptide screening for antibacterial and antifungal activity.

Author Contributions: Conceptualization, J.P. and K.-W.L.; methodology, J.-G.K. and H.C.; validation, J.-G.K., S.N. and K.V.; investigation, J.-G.K. and K.-Y.K.; resources, K.-W.L.; data curation, H.C. and S.N.; writing—original draft preparation, K.V.; writing—review and editing, H.C., J.P. and K.-Y.K. All authors have read and agreed to the published version of the manuscript.

Funding: This research was funded by 3BIGS Research Fund, grant number 3BIGS-R-20190012.

Data Availability Statement: The transcriptome data is deposited in the National Center for Biotechnology (NCBI) Sequence Read Archive (SRA) under the accession number SRA1102671.

Conflicts of Interest: The authors declare no conflict of interest.

\section{References}

1. Huan, Y.; Kong, Q.; Mou, H.; Yi, H. Antimicrobial Peptides: Classification, Design, Application and Research Progress in Multiple Fields. Front. Microbiol. 2020, 11, 582779. [CrossRef] [PubMed]

2. Christaki, E.; Marcou, M.; Tofarides, A. Antimicrobial Resistance in Bacteria: Mechanisms, Evolution, and Persistence. J. Mol. Evol. 2020, 88, 26-40. [CrossRef] [PubMed]

3. Lopez Romo, A.; Quiros, R. Appropriate use of antibiotics: An unmet need. Ther. Adv. Urol. 2019, 11, 1756287219832174. [CrossRef] [PubMed]

4. Lee, J.H.; Chung, H.; Shin, Y.P.; Kim, M.A.; Natarajan, S.; Veerappan, K.; Kim, S.H.; Park, J.; Hwang, J.S. Deciphering Novel Antimicrobial Peptides from the Transcriptome of Papilio xuthus. Insects 2020, 11, 776. [CrossRef]

5. Lee, J.H.; Chung, H.; Shin, Y.P.; Kim, I.W.; Natarajan, S.; Veerappan, K.; Seo, M.; Park, J.; Hwang, J.S. Transcriptome Analysis of Psacothea hilaris: De Novo Assembly and Antimicrobial Peptide Prediction. Insects 2020, 11, 676. [CrossRef]

6. Park, Y.; Kim, Y.; Park, G.-W.; Lee, J.-O.; Lee, K.-W. Supercooling capacity along with up-regulation of glycerol content in an overwintering butterfly, Parnassius bremeri. J. Asia-Pac. Entomol. 2017, 20, 949-954. [CrossRef]

7. Brady, D.; Grapputo, A.; Romoli, O.; Sandrelli, F. Insect Cecropins, Antimicrobial Peptides with Potential Therapeutic Applications. Int. J. Mol. Sci. 2019, 20, 5862. [CrossRef]

8. Buonocore, F.; Fausto, A.M.; Della Pelle, G.; Roncevic, T.; Gerdol, M.; Picchietti, S. Attacins: A Promising Class of Insect Antimicrobial Peptides. Antibiotics 2021, 10, 212. [CrossRef]

9. Badapanda, C.; Chikara, S.K. Lepidopteran Antimicrobial Peptides (AMPs): Overview, Regulation, Modes of Action, and Therapeutic Potentials of Insect-Derived AMPs. In Short Views on Insect Genomics and Proteomics: Insect Proteomics; Raman, C., Goldsmith, M.R., Agunbiade, T.A., Eds.; Springer International Publishing: Cham, Switzerland, 2016; Volume 2, pp. $141-163$. [CrossRef]

10. Willis, J.R.; Gabaldon, T. The Human Oral Microbiome in Health and Disease: From Sequences to Ecosystems. Microorganisms 2020, 8, 308. [CrossRef]

11. Suwandecha, T.; Srichana, T.; Balekar, N.; Nakpheng, T.; Pangsomboon, K. Novel antimicrobial peptide specifically active against Porphyromonas gingivalis. Arch. Microbiol. 2015, 197, 899-909. [CrossRef] [PubMed]

12. Wang, H.; Ai, L.; Zhang, Y.; Cheng, J.; Yu, H.; Li, C.; Zhang, D.; Pan, Y.; Lin, L. The Effects of Antimicrobial Peptide Nal-P-113 on Inhibiting Periodontal Pathogens and Improving Periodontal Status. Biomed Res. Int. 2018, 2018, 1805793. [CrossRef] 
13. Taniguchi, M.; Ochiai, A.; Takahashi, K.; Nakamichi, S.I.; Nomoto, T.; Saitoh, E.; Kato, T.; Tanaka, T. Antimicrobial activity against Porphyromonas gingivalis and mechanism of action of the cationic octadecapeptide AmyI-1-18 and its amino acid-substituted analogs. J. Biosci. Bioeng. 2016, 122, 652-659. [CrossRef] [PubMed]

14. FASTQC. Available online: https://www.bioinformatics.babraham.ac.uk/projects/fastqc/ (accessed on 16 April 2021).

15. Bolger, A.M.; Lohse, M.; Usadel, B. Trimmomatic: A flexible trimmer for Illumina sequence data. Bioinformatics 2014, 30, 2114-2120. [CrossRef] [PubMed]

16. Haas, B.J.; Papanicolaou, A.; Yassour, M.; Grabherr, M.; Blood, P.D.; Bowden, J.; Couger, M.B.; Eccles, D.; Li, B.; Lieber, M.; et al. De novo transcript sequence reconstruction from RNA-seq using the Trinity platform for reference generation and analysis. Nat. Protoc. 2013, 8, 1494-1512. [CrossRef]

17. Li, W.; Godzik, A. Cd-hit: A fast program for clustering and comparing large sets of protein or nucleotide sequences. Bioinformatics 2006, 22, 1658-1659. [CrossRef] [PubMed]

18. Nishimura, O.; Hara, Y.; Kuraku, S. gVolante for standardizing completeness assessment of genome and transcriptome assemblies. Bioinformatics 2017, 33, 3635-3637. [CrossRef] [PubMed]

19. Madeira, F.; Park, Y.M.; Lee, J.; Buso, N.; Gur, T.; Madhusoodanan, N.; Basutkar, P.; Tivey, A.R.N.; Potter, S.C.; Finn, R.D.; et al. The EMBL-EBI search and sequence analysis tools APIs in 2019. Nucleic Acids Res. 2019, 47, W636-W641. [CrossRef] [PubMed]

20. Fernandez-Escamilla, A.M.; Rousseau, F.; Schymkowitz, J.; Serrano, L. Prediction of sequence-dependent and mutational effects on the aggregation of peptides and proteins. Nat. Biotechnol. 2004, 22, 1302-1306. [CrossRef] [PubMed]

21. Conchillo-Sole, O.; de Groot, N.S.; Aviles, F.X.; Vendrell, J.; Daura, X.; Ventura, S. AGGRESCAN: A server for the prediction and evaluation of "hot spots" of aggregation in polypeptides. BMC Bioinform. 2007, 8, 65. [CrossRef] [PubMed]

22. Torrent, M.; Di Tommaso, P.; Pulido, D.; Nogues, M.V.; Notredame, C.; Boix, E.; Andreu, D. AMPA: An automated web server for prediction of protein antimicrobial regions. Bioinformatics 2012, 28, 130-131. [CrossRef]

23. Waghu, F.H.; Gopi, L.; Barai, R.S.; Ramteke, P.; Nizami, B.; Idicula-Thomas, S. CAMP: Collection of sequences and structures of antimicrobial peptides. Nucleic Acids Res. 2014, 42, D1154-D1158. [CrossRef] [PubMed]

24. Lee, H.T.; Lee, C.C.; Yang, J.R.; Lai, J.Z.; Chang, K.Y. A large-scale structural classification of antimicrobial peptides. Biomed Res. Int. 2015, 2015, 475062. [CrossRef] [PubMed]

25. Wang, G.; Li, X.; Wang, Z. APD3: The antimicrobial peptide database as a tool for research and education. Nucleic Acids Res. 2016, 44, D1087-D1093. [CrossRef]

26. Kim, J.; Park, S.; Shin, Y.-K.; Kang, H.; Kim, K.-Y. In vitro antibacterial activity of macelignan and corosolic acid against the bacterial bee pathogens Paenibacillus larvae and Melissococcus plutonius. Acta Vet. Brno 2018, 87, 277-284. [CrossRef]

27. Park, S.; Kim, J.; Shin, Y.-K.; Kim, K.-Y. Antimicrobial activity of 4-hydroxyderricin, sophoraflavanone G, acetylshikonin, and kurarinone against the bee pathogenic bacteria Paenibacillus larvae and Melissococcus plutonius. J. Apic. Res. 2020, 1-5.

28. Jenssen, H.; Hamill, P.; Hancock, R.E. Peptide antimicrobial agents. Clin. Microbiol. Rev. 2006, 19, 491-511. [CrossRef] [PubMed]

29. Mahlapuu, M.; Hakansson, J.; Ringstad, L.; Bjorn, C. Antimicrobial Peptides: An Emerging Category of Therapeutic Agents. Front. Cell. Infect. Microbiol. 2016, 6, 194. [CrossRef]

30. Pasupuleti, M.; Schmidtchen, A.; Malmsten, M. Antimicrobial peptides: Key components of the innate immune system. Crit. Rev. Biotechnol. 2012, 32, 143-171. [CrossRef]

31. Torrent, M.; Andreu, D.; Nogues, V.M.; Boix, E. Connecting peptide physicochemical and antimicrobial properties by a rational prediction model. PLoS ONE 2011, 6, e16968. [CrossRef]

32. Bostanci, N.; Belibasakis, G.N. Porphyromonas gingivalis: An invasive and evasive opportunistic oral pathogen. FEMS Microbiol. Lett. 2012, 333, 1-9. [CrossRef]

33. Xu, W.; Zhou, W.; Wang, H.; Liang, S. Roles of Porphyromonas gingivalis and its virulence factors in periodontitis. Adv. Protein Chem. Struct. Biol. 2020, 120, 45-84. [CrossRef] [PubMed]

34. Olsen, I.; Taubman, M.A.; Singhrao, S.K. Porphyromonas gingivalis suppresses adaptive immunity in periodontitis, atherosclerosis, and Alzheimer's disease. J. Oral. Microbiol. 2016, 8, 33029. [CrossRef] [PubMed]

35. Kanagasingam, S.; Chukkapalli, S.S.; Welbury, R.; Singhrao, S.K. Porphyromonas gingivalis is a Strong Risk Factor for Alzheimer's Disease. J. Alzheimers Dis. Rep. 2020, 4, 501-511. [CrossRef] [PubMed] 